\title{
Sanctity and Suffering: The Sacred World of the Medieval Leprosarium. A Perspective from St Mary Magdalen, Winchester
}

\author{
Simon Roffey
}

The first documented leprosy hospitals date from the late 11th century and it is generally believed that this period marks their first introduction into AngloNorman society. ${ }^{1}$ However, there is certainly a prior context for related medical practice as well as the treatment of the ill and infirm in Pre-Norman England. Moreover, there is an increasing body of evidence for an increase in leprosy in the centuries leading up to the first documented foundations of leprosy hospitals, which suggests that the Normans may have institutionalised an already prevailing and progressively emergent disease. ${ }^{2}$ This paper, based on ten years of research on the former leprosarium of St Mary Magdalen, Winchester, will provide an archaeological and historical reassessment of the social context of leprosy and the status of its institutions in medieval society (Fig. 25.1). Furthermore, it will also argue that the status of leprosaria were more akin to religious communities rather than wholly marginalized places for exclusion.

\section{Leprosaria: The Early Medieval Background}

Leprosy has been claimed to have been a "social problem" by at least by 1044, when the leprous bishop, Ælfweard of London, was required to resign his bishopric. ${ }^{3}$ That being said, skeletal evidence for leprosy is comparatively rare, apart from a few individual examples, and there is no archaeological

1 See Simon Roffey, "Charity and Conquest: Leprosaria in Early Norman England," in The Archaeology of the nth Century: Continuities and Transformations, ed. Dawn M. Hadley and Christopher Dyer, Society of Medieval Archaeology Monograph 38 (London and New York, 2017), pp. 170-80.

2 For a recent overview of skeletal evidence from Anglo-Saxon England see Sarah Inskip, G. Michael Taylor, Sue Anderson and Graham Stewart, "Leprosy in Pre-Norman Suffolk, UK: Biomolecular and Geochemical Analysis of the Woman from Hoxne," Journal of Medical Microbiology 66 (2017), 1640-49.

3 Nicholas Orme and Margaret Webster, The English Hospital 1070-1570 (New Haven, CT, 1995), p. 24. 


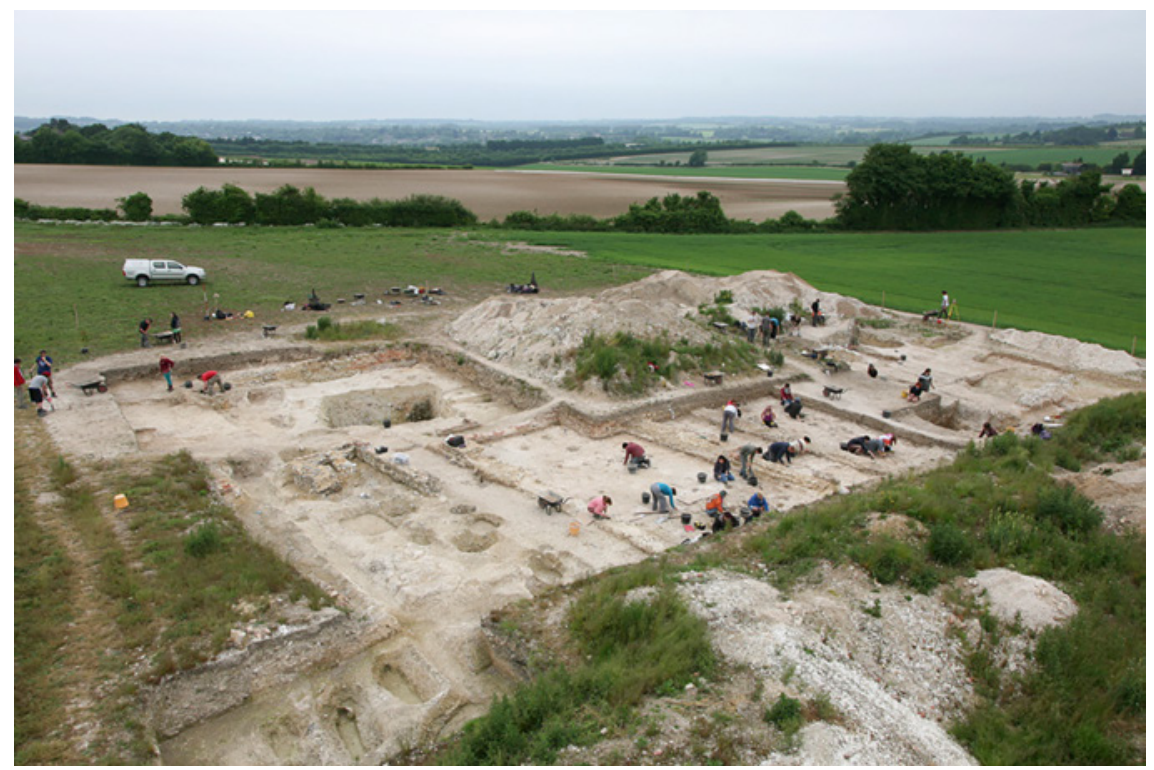

FIGURE 25.1 The excavations of St Mary Magdalen, Winchester, looking west towards the City

(C) THE AUTHOR

evidence for pre-Conquest hospitals in England. Perhaps the most intriguing evidence for a pre-Conquest community, or at least a defined cemetery group, comes from the excavations of the medieval churchyard at Castle Mall, Norwich, which revealed a series of burials which presented skeletal evidence of leprosy. Radiocarbon dates of eighteen individuals showed that the burial ground came into use in cal AD 980-1030 (95 per cent probability) and went out of use in cal AD 990-1050 (95 per cent probability). ${ }^{4}$ Related artefacts recovered from the graves were generally of a late Saxon/Norman type. No related buildings were found to suggest the cemetery was part of a hospital complex, but it is entirely possible that any buildings, the majority likely of timber, had been destroyed by later burials, or even lie under the site of the later church itself.

The practice of medicine was already widespread in England prior to the Norman Conquest and physicians were a feature of Anglo-Saxon society from at least the 9th century. Alfred's biographer, Asser, relates, for example, that the king, who seems to have suffered from various illnesses, was often tended by

4 Elizabeth Shepherd-Popescu, Norwich Castle: Excavations and Historical Survey 1987-98, Part I: Anglo-Saxon to c.1345, East Anglian Archaeology 132 (Norwich, 2009). 
physicians (medici), possibly attached to the royal court. ${ }^{5}$ The curing of people with leprosy does feature in some of the hagiographic and homiletic writings of the late Anglo-Saxon period. Ælfric, who spent much of his early monastic life in Winchester, in his Lives of Saints, presents a story of St Martin healing leprosy sufferers outside the gates of Paris. ${ }^{6}$ Medical treatises of the late 9th and 1oth centuries, including the Old English Herbarium and the Lacnunga refer to a range of skin ailments, some of which may have been leprosy. ${ }^{7}$ The socalled Bald's Leechbook, of the late 9th or early 1oth century, a work with possible Winchester connections, refers to the disease more directly as a "white roughness" (hwite riefpo) which "is called leprosy in the south." ${ }^{\text {L Late Anglo- }}$ Saxon society certainly presented both the conditions and a socio-religious context for the evolution of the hospital. A fragmentary documentary record and growing archaeological evidence for leprosy in the pre-Conquest period may suggest an acute progression of leprosy leading to the institutionalisation of the disease in the first few decades of the Norman Conquest.

The late 11th and early 12 th centuries witnessed the foundation of dedicated leprosy hospitals, often on the margins of European urban settlements. The implications of this marginal location, as well as related issues concerning contagion and religious exclusion, has led many traditional historians to view these institutions and their occupants as being excluded or marginalized from medieval society. This has consequently given rise to the popular (mis)conception of the 'leper as outcast' which has dominated the public imagination even into the 2oth and 21st centuries. ${ }^{9}$ In contrast, however, recent archaeological research on medieval leprosy hospitals suggests that many early institutions may have operated more as quasi-religious communities, with houses, chapels and organised cemeteries. Evidence from sites such as Winchester, one of the most comprehensively excavated examples, suggests a quality of life and status in death that runs contrary to traditional perceptions of people with leprosy

5 Asser, ch. 74. David Pratt, "The Illnesses of King Alfred the Great," ASE 30 (2001), 39-90, at p. 39 .

6 Elfric's Lives of Three English Saints, ed. and trans. Geoffrey I. Needham (Exeter, 1976), p. 69.

7 Sally Crawford, "The Nadir of Western Medicine? Texts, Contexts and Practice in Anglo-Saxon England," in Bodies of Knowledge: Cultural Interpretations of Illness and Medicine in Medieval Europe, ed. Sally Crawford and Christina Lee, Studies in Early Medicine 1: BAR Int. Ser. 2170 (Oxford, 2010), pp. 41-52.

8 Christina Lee, "Changing Faces: Leprosy in Anglo-Saxon England," in Conversion and Colonization in Anglo-Saxon England, ed. Catherine Karkov and Nicholas Howe (Tempe, AZ, 2006), pp. 59-81, at p. 75. The reference is in Leechdoms, Wortcunning, and Starcraft of Early England, ed. Oswald Cockayne, RS 35, 3 vols (London, 1864-6), 2:228-29.

9 See e.g. Saul Brody, The Disease of the Soul: Leprosy in Medieval Literature (London, 1974). 
and their social context. ${ }^{10}$ This research further supports recent revisionist approaches to medieval leprosy which argue that in some cases leprosy articulated a 'sanctity in suffering' and was a mark of divine favour. ${ }^{11}$ Moreover, in the wider medieval landscape, rather than being segregated and excluded institutions, these communities were in fact an important and integral component of a broader sacred landscape in the medieval urban hinterlands.

\section{Medieval Leprosy: Perceptions and Misperceptions}

In the medieval period leprosy was endemic to most of Asia, the Middle East and Europe. Today leprosy, or Hansen's disease as it is more commonly known, is a disease that still continues to impact on people in many countries, and the 'shame' of its affliction is still apparent in modern societies. ${ }^{12}$ In this light any revision of early leprosy 'hospitals' as religious communities, with a special status in medieval society, should contribute to a more empathetic perspective. It can help challenge and address traditional misconceptions of the disease and its status in past society, and, in a wider global perspective, further an understanding of leprosy and the roots of discrimination in contemporary society. It has been claimed that much of the discrimination towards people with leprosy today ultimately stems from a biomedical segregationist agenda of the 19th century. ${ }^{13}$ This is an agenda, developed in traditional academic disciplines, that can still be found within contemporary scholarship about leprosy and its history ${ }^{14}$ Despite the substantial progress made in the modern control of leprosy, discrimination has persisted partly because most languages have framed the word 'leprosy' as a synonym for indignity and stigma since the Middle Ages.

Early references to the treatment of people with leprosy can be found in Biblical sources, particularly the Book of Leviticus. Levite laws dealing with

10 Simon Roffey and Katie Tucker, "A Contextual Study of the Medieval Hospital and Cemetery of St Mary Magdalen, Winchester, England," International Journal of Paleopathology 2:4 (2012), 170-80; Simon Roffey, "Medieval Leper Hospitals in England: an Archaeological Perspective from St Mary Magdalen, Winchester," Medieval Archaeology 56 (2012), 203-33.

11 Simon Roffey and Phil Marter, "Treating Leprosy: St Mary Magdalen, Winchester," Current Archaeology 267 (2012), 12-18.

12 See <https://www.lepra.org.uk/News/history-and-heritage-of-leprosy> for example (accessed 24 May 2018).

13 See Carole Rawcliffe, Leprosy in Medieval England (Woodbridge 2006), pp. 17-29 for a more detailed discussion of leprosy and the origins of discrimination.

14 See Roffey, "Medieval Leper Hospitals in England" for a more detailed discussion. 
ritual impurity stated that anyone with signs of leprosy were to be "led" or brought to the priest and consequently consigned to live "outside the camp."15 Later, echoes of this injunction can perhaps be found in later regulations and decrees such as Canon 23 of the 1179 Third Lateran Council, which stated that people with leprosy should not dwell among the healthy. ${ }^{16}$ Here, the implied prohibition of such decrees would present one explanation as to why the majority of medieval leprosy hospitals were founded on the outskirts of towns. Consequently, the liminal treatment of people with leprosy has also been held to be akin to the treatment of criminals in the medieval period who were often buried on the boundaries and outskirts of towns. ${ }^{17}$ In this respect, it has been suggested that leprosaria offered an alternative place for the burial of criminals. Excavations at the hospital of St Giles, Brompton Bridge (N. Yorks.) revealed the burial of an individual with leprosy placed on the hospital boundary. This was accordingly interpreted as that of a criminal or suicide. ${ }^{18}$ However, apart from the location of the burial it is unclear as to how this interpretation has been reached, ${ }^{19}$ and the archaeological evidence for the burial of criminals in leprosy hospitals is otherwise unconvincing. In contrast, as we shall see below, archaeological evidence from St Mary Magdalen, Winchester, reveals that the dead were treated with a level of dignity and respect, which perhaps reveals a more complex picture regarding their social status.

One common misunderstanding regarding leprosy in the medieval period is the belief that the disease was believed by medieval society to be contagious and was the specific reason why leprosaria were located outside of town boundaries. Thus, leprosy was "feared for its contagiousness" and thus "in their intent," hospitals "were established to confine lepers (and so the disease) and to keep them alive." ${ }^{20}$ Consequently "the leper was a threat to society, the carrier of contagion, and society did what it could to protect itself."21 However, this may not have necessarily been the case and may be a largely anachronistic interpretation. Classical medical literature does not present any clear evidence

15 Leviticus 13:2, 7, 9 and 19; Leviticus 13:46, 14:2.

16 Norman, P. Tanner, ed. and trans., Decrees of the Ecumenical Councils (London, 1990), pp. 222-23.

17 Christopher Daniell, "Conquest, Crime and Theology in the Burial Record 1066-1200," in Burial in Early Medieval England and Wales, ed. Sam Lucy and Andrew Reynolds, Society of Medieval Archaeology Monograph 17 (London, 2002), pp. 241-25, at p. 246.

18 Peter Cardwell, "Excavation of the Hospital of St Giles by Brompton Bridge, North Yorkshire," Archaeological Journal 152 (1995), 109-245, at p. 128.

19 It is also possible that the burial may date from the later phases of the hospital when it ceased to function primarily as a leprosarium.

20 Brody, Disease of the Soul, pp. 6o, 75 .

21 Brody, Disease of the Soul, p. 79. 
that the disease had been classified as a transmissible disease ${ }^{22}$ and indeed the first appearance of views on the contagiousness of leprosy only emerged between $c .1220-30$, some 150 years after the first recorded foundation of leprosy hospitals. ${ }^{23}$ In 1363 Guy de Chauliac was the first textbook author to make the connection by labelling the disease "contagious and infectious," ${ }^{24}$ although the foundation of leprosaria, as hence the disease itself, was in decline well before this time..$^{25}$ It is therefore reasonable to conclude that perceived views of people with leprosy, and the consequent location of the hospitals to which they are admitted, was not necessarily related to notions of disease transmission. Furthermore, it also challenges the idea of stigmatization, since contagiousness is often held as the primary reason for the specific location of hospitals.

\section{Hospital in the Landscape: Practicalities and Provision}

Almost all medieval leprosy hospitals were founded on the edge of towns or in the immediate urban hinterland. ${ }^{26}$ As noted, this specific location would naturally support the idea that hospitals were placed famously 'outside the camp'. In this sense, however, it could be argued that in such instances we may be ultimately looking at the treatment of the disease itself rather than the diseased. ${ }^{27}$ Nonetheless, it should also be noted that many other types of medieval hospital were found outside of towns, as at Canterbury, London and Winchester. This liminal location can also be applied to some urban monasteries, particularly friaries. Since, as we have noted above, a need for quarantine was not necessarily the prime motive behind the foundation of a hospital, at

22 Antje M. Schelberg "Morbus regius'-No Case for the Medieval Leprosy Examination Boards," in The Myths of Mediaeval Leprosy: A Collection of Essays, ed. Antje M Schelberg, (Göttingen, 2006), pp. 1-15, at p. 8.

23 Justin K. Stearns, Infectious Ideas: Contagion in Pre-Modern Islamic and Christian Thought in the Western Mediterranean (Baltimore 2011), pp. 49, 102-51. For a wider discussion of contagion and leprosy see also Francois Olivier Touati, Maladie et société au moyen âge. la lèpre, les lépreux et les léproseries dans la province ecclésiastique de Sens jusqu'au milieu du XIVe siècle (Brussels, 1998); idem, "Contagion and Leprosy: Myths, Ideas and Evolution in Medieval Minds and Societies," in Contagion: Perspectives from Premodern Societies, ed. Lawrence, I. Conrad and Dominik Wujastyk (Aldershot, 1999), pp. 161-83.

24 Luke Demaitre, Leprosy in Premodern Medicine : A Malady of the Whole Body (Baltimore, 2007), p. 40.

25 Roffey, "Medieval Leper Hospitals in England," p. 214.

26 Roffey, "Medieval Leper Hospitals in England."

27 Roffey, "Charity and Conquest" p.172. 
least prior to $c .1300$, there must therefore be other possible reasons for leprosy hospitals being placed outside of medieval towns. These include proximity to important roads (i.e. London, Old Sarum, Norwich, Winchester and Southampton), a source of water (in the example of Bath, located on the bank of the river Avon), and ultimately the availability of land which would have been presumably more feasible on the outskirts of the town by the 12th century. At Norwich, all five leprosy hospitals were founded by the town's entrances. ${ }^{28}$ Here perhaps one cannot imagine a more inappropriate place for a hospital if there was a fear of contagion. Such places would have been particularly busy and were often the location for markets or town gatherings. Overall self-sufficiency, rather than exclusivity, was the fundamental reason behind the siting of leprosy hospitals in and around towns. Here, in such visible and physically accessible places there would be perhaps greater capacity for attracting charity and alms-giving. In most examples, the leprosarium would be the first (or last) religious institution travellers and merchants came across when approaching or leaving a town. Such a position would have served as a potent symbol of civic charity and responsibility. At Southampton, the leprosy hospital, founded by the civic authorities, occupied several hundred metres of land, north of the Bargate, either side of the King's Highway to Winchester. ${ }^{29}$

The placing of many hospitals on major roads into towns also presented potent status symbols for their founders, often bishops, and by implication required visually impressive and well-appointed buildings. In this sense these pious, and visible, symbols would have effectively branded the landscape and, as we will see, arguably formed an important component in a wider network of religious sites in the medieval landscape. In this light such institutions may be viewed rather as religious communities than consolidated groups of outcasts. Furthermore, it is also possible that leprosaria may have been founded to create a monastic setting in which their inmates could pursue a primarily religious vocation, ${ }^{30}$ and thus arguably of a status on par with that afforded to some minor monastic communities of the time.

\footnotetext{
28 Rawcliffe, Leprosy in Medieval England, p. 313, map 5.

29 Alan, D. Morton and Vaughan Birbeck, "Archaeological and Documentary Evidence of Southampton's Leper House," in PHFCAS 67:1 (2012), 210-18.

30 Elma Brenner, "Outside the Walls: Leprosy, Exclusion, and Social Identity in Twelfth and Thirteenth Century Rouen," in Difference and Identity in Francia and Medieval France, ed. Meredith Cohen and Justine Marie Firnhaber-Baker (Aldershot, 2010), pp. 139-56, at p. 142.
} 


\section{Sanctity in Suffering}

Prior to the 14th century, a period that may coincide with a growing understanding of disease transmission and contagion, there is some historical evidence to suggest that leprosy was believed to be a mark of divine favour, and its occurrence a religious calling and a "passport to paradise". ${ }^{31}$ In this context, the suffering associated with leprosy was viewed by some medieval theologians, such as St Hugh of Lincoln (c.1135-1200), as a form of purgatorial hardship and akin to the sufferings of Christ himself. ${ }^{32}$ As early as the 4th century AD Gregory of Nazianzus (c.325-39o) had referred to it as a sacred malady, and the Bishop of Tournai in 1239 claimed the disease as a gift from God. ${ }^{33}$ In such instances, we may view related leprosy communities as representative of a type of religious calling, rather than imposed segregation, albeit with the proviso that the two are not necessarily mutually exclusive in all cases. It is here that archaeological evidence can add much to the debate where excavated examples and extant buildings from important medieval towns such as Rouen, France, and Winchester and Norwich in England indicate well-provisioned communities. Although it is unclear as to what extent such beliefs concerning leprosy and the vocational status of sufferers were universally held and, indeed, for how long, the archaeological evidence from the early phases at Winchester does go some way to support such a status.

Archaeological research at the medieval leprosy hospital of St Mary Magdalen, Winchester, one of the earliest dated examples from Western Europe (c.1070-90), has contributed much to the ongoing debate. Here, excavations have revealed the possible presence of an early religious community of people with leprosy, comprising evidence for former timber structures, a small masonry chapel and an organised cemetery (Fig. 25.2). ${ }^{34}$ The archaeological evidence compares well with the earliest documented foundation at Harbledown, Canterbury (c.108os). Here, a contemporary description refers to a chapel, timber houses and cemetery on the shelf of a hill. ${ }^{35}$ At Winchester the primary phase of occupation had ended by the mid-12th century when a new chapel was constructed together with a masonry infirmary and associated structures. The cemetery was also decommissioned at this time, and a new cemetery laid out to the south of the chapel.

31 Rawcliffe, Leprosy in Medieval England, pp. 58-59.

32 Rawcliffe, Leprosy in Medieval England, p. 59.

33 Brody, Disease of the Soul, p. 101.

34 Roffey, "Medieval Leper Hospitals in England."

35 Eadmer, Eadmer's History of Recent Events in England, ed. and trans. Geoffrey Bosanquet (London, 1964), 25; see also Roffey, "Charity and Conquest." 


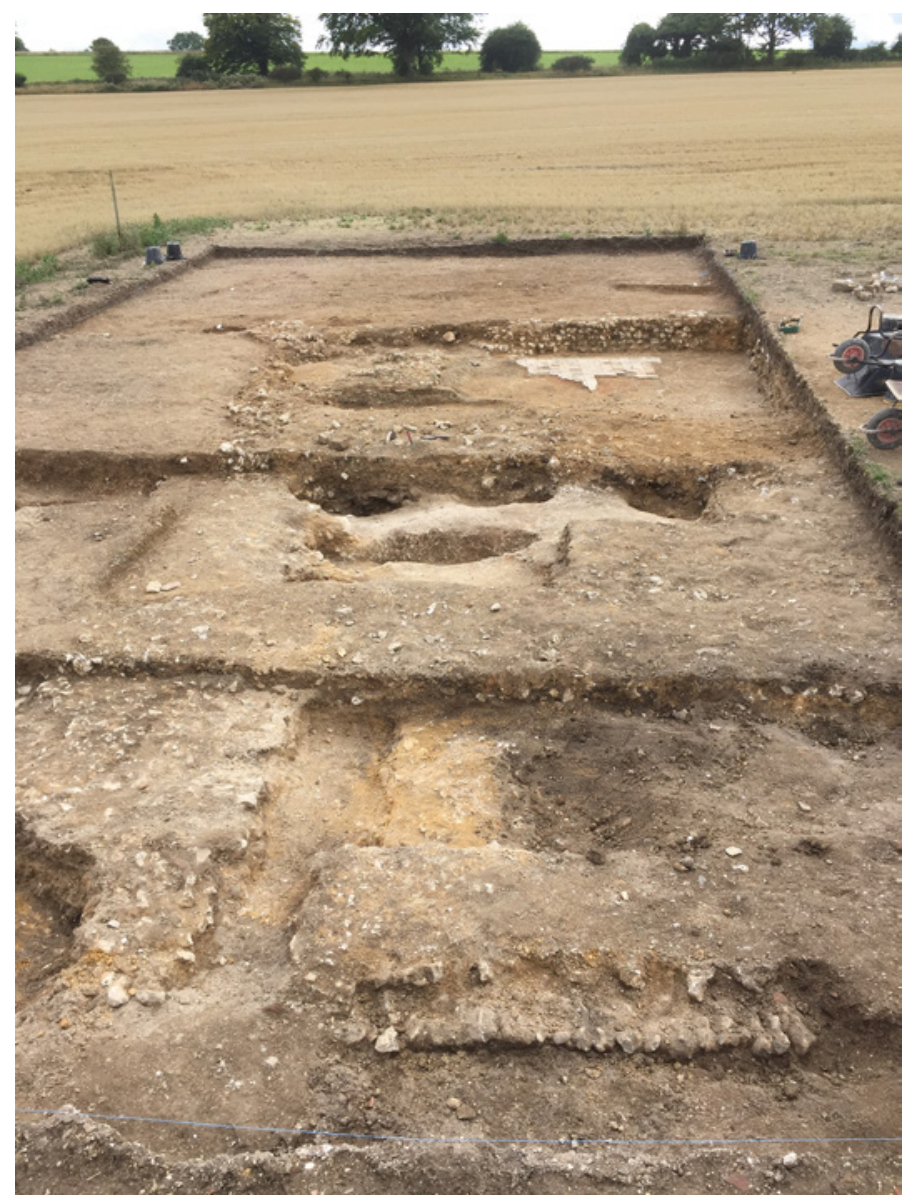

FIGURE 25.2 View of the east end of the mid-12th-century chapel (looking south). The north-south running wall with the sandy mortar in the foreground represents the remains of the east end of the smaller and earlier chapel dating to around the first few decades of the Norman Conquest (C) THE AUTHOR

Analysis of the cemetery material from Winchester was radiocarbon dated to the late 11th and early 12 th centuries, and revealed skeletal evidence for leprosy in over $85 \%$ of excavated skeletons, a much larger percentage than has previously been recorded from any British site or anywhere else. ${ }^{36}$ The high proportion of people with leprosy noted in the cemetery also suggests that medical diagnosis of the disease was very precise. There was also evidence from the

$36 \quad$ Roffey and Tucker, "A Contextual Study." 


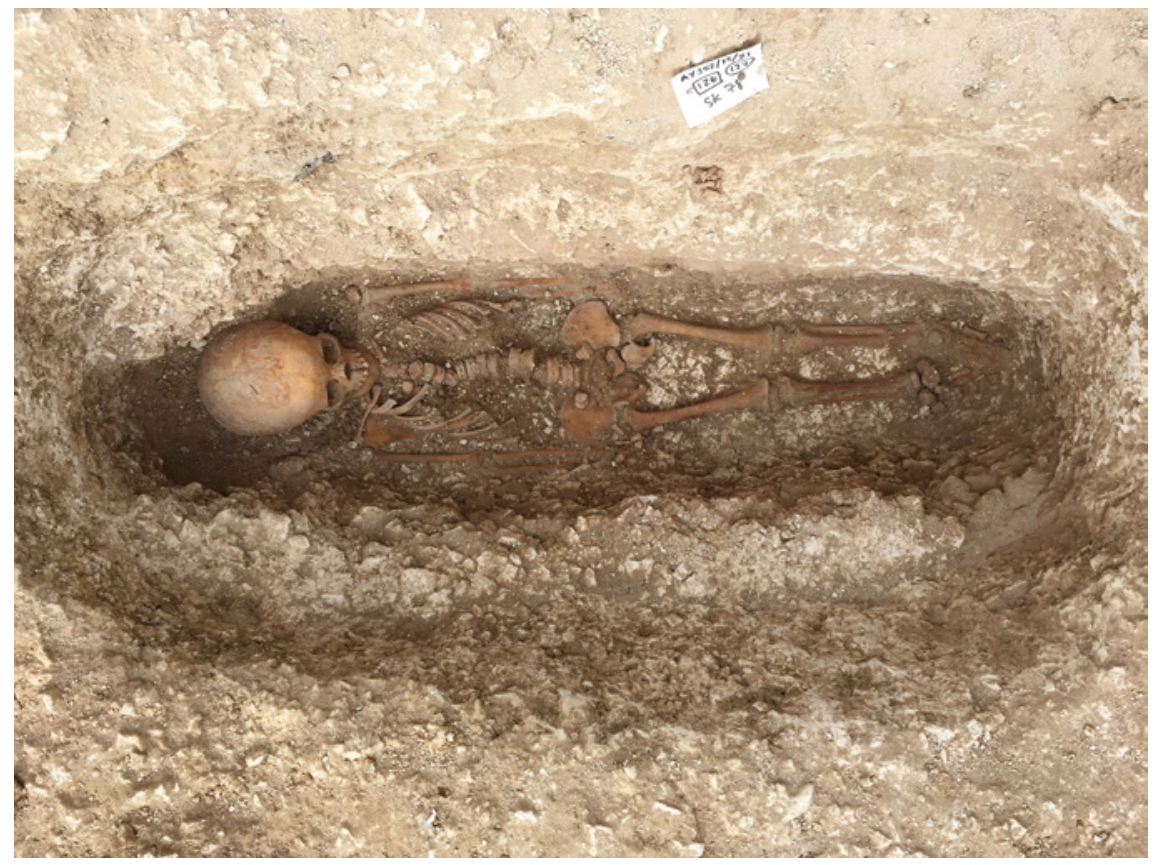

FIGURE 25.3 Burial from the cemetery of St Mary Magdalen. Note the grave cut with ledge and head niche

(C) THE AUTHOR

hospital, in one example, for remedial and surgical care in the form of a leg amputation with subsequent healing. ${ }^{37}$ Together this points to the likelihood of a specialist institution and one that may have been founded as a direct contingency against the dramatic rise of the disease in the later 11th century. Overall, the evidence from Winchester shows a level of personal and communal, and possibly professional, provision that suggests an elevated level of social status, perhaps on par with minor monastic houses of the period.

The burials comprised men, women and children indicating a mixed community. The burials of these individuals are of some significance. Very few of the graves intercut, suggesting they had been marked. Furthermore, the form of graves was anthropomorphic, tapered with cut niches for the head. Many graves had evidence for ledges indicating that they were either covered by ledger slabs or, more likely, wooden boards (Fig. 25.3). The anthropomorphic style of burial is normally only otherwise found in the context of monastic burial, an example being the nearby abbey of St Mary's (Nunnaminster) in Winchester. 
Further afield, examples include the Cistercian abbey of Langthorne, Essex, the Benedictine priory of St Neots, Cambs., and St James's Priory, Bristol, among others. ${ }^{38}$ At St Mary Magdalen, Winchester, this was also a form of burial that was applied equally to male and female burials as well as, unusually, to neonate burials. If can thus be argued that these burials were treated as burials of the religious; a status afforded all members of the community (including babies), with the only condition being that all individuals had evidence of leprosy. This may again confirm that, at least at Winchester, the community was not viewed as contagious outcasts but rather as a religious community, with leprosy as a form of 'divine calling' and vocation.

\section{Pilgrim Burial}

One of the burials present at the leprosarium of St Mary Magdalen, Winchester, represents the only example of a pilgrim burial with a scallop shell in a medieval leprosy hospital cemetery. ${ }^{39}$ Osteological and scientific analysis indicated that the pilgrim had experienced early onset of leprosy, although the disease was probably not the direct cause of death sometime in the early 12th century. It is therefore likely that the pilgrim had contracted the disease fairly recently and raises the possibility that he had come into contact with a carrier of the disease, possibly asymptomatic, during his travels. ${ }^{40}$ The individual was accompanied by a scallop shell with two pierced holes that was found on the left side of the pelvis (Fig. 25.4). The two small holes were presumably for attachment to a scrip or bag which no longer survived. Together with the pilgrim's staff and hat, the scrip, which in appearance would have resembled a pouch, had a symbolic as well as practical function and was often blessed before pilgrimage. ${ }^{41}$ Scallop shells badges have been found in other religious contexts including Lichfield and Worcester Cathedrals and Hulton Abbey, Staffs. ${ }^{42}$ This type of badge has long been associated with pilgrimage to the shrine of St James the Great at the Cathedral of Santiago de Compostela, Galicia, Spain,

38 Roberta Gilchrist and Barney Sloane, Requiem: The Medieval Monastic Cemetery in Britain (London 2005).

39 Simon Roffey, Katie Tucker, Kori Filipek-Ogden, et al., "Investigation of a Medieval Pilgrim Burial Excavated from the Leprosarium of St Mary Magdalen Winchester, UK," PLOS Neglected Tropical Diseases 11:1 (2017), 1-27.

40 Roffey, Tucker, Filipek-Ogden, et al., "Investigation of a Medieval Pilgrim Burial."

41 Roffey, Tucker, Filipek-Ogden, et al., "Investigation of a Medieval Pilgrim Burial." See also for comparative examples of pilgrim burials with scallop shells.

Gilchrist and Sloane, Requiem, p. 127. 


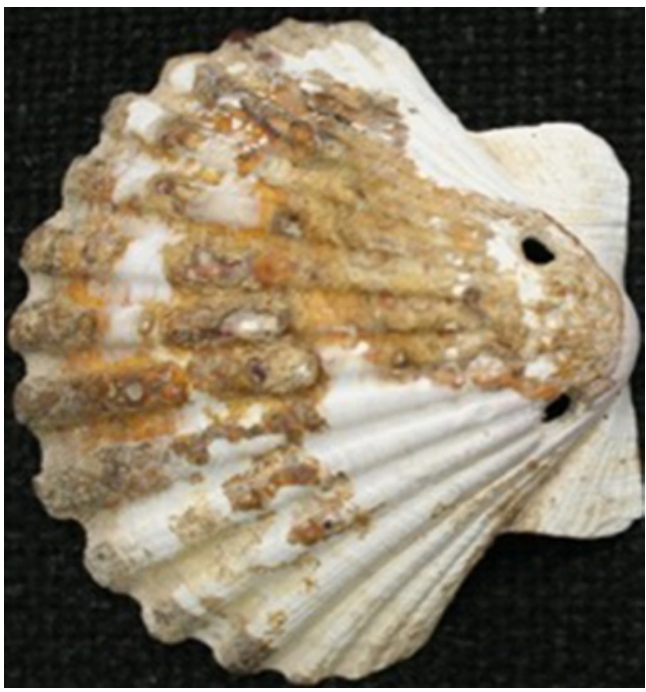

FIGURE 25.4

Scallop shell pilgrim badge from St Mary Magdalen dating to the first few decades of the 12th century. Note the small holes which would have been used to attach the shell to the pilgrim's bag or scrip

(C) THE AUTHOR

since at least 1130.43 The shrine of St James at Santiago de Compostela, Spain, together with Jerusalem and Rome, was one of the three great pilgrimages of the medieval period. ${ }^{44}$ However, pilgrimage was an international phenomenon, and saints' shrines (often contexts for miraculous cure of illness and disease) were numerous throughout medieval Europe. In England, the principle pilgrim centres were Canterbury and Walsingham. However, Winchester was also an important and popular pilgrim centre in its own right.

By the early 12th century, Winchester was a bustling and cosmopolitan city. Replete with shrines, religious institutions and hospitals it also represented a central place in the pilgrimage landscape. The city housed several important relics, including those of the Saints Swithun, Birinus, Judoc and Grimbald. The city was also central to a network of pilgrim routes in the south of England stretching from Glastonbury in the west to Canterbury in the east. To the north of Winchester lay Reading Abbey, which was one of the most important pilgrimage sites in Western Europe. ${ }^{45}$ In the 12th century, Reading had acquired the hand of St James, formerly held by the German Imperial Treasury and

43 John Cherry, "The Depiction of St James Compostela on Seals," in Beyond Pilgrim Souvenirs and Secular Badges: Essays in Honour of Brian Spencer, ed. Sarah Blick (Oxford, 2007), pp. $37-47$, at p. 40 .

44 Simon Roffey, Chantry Chapels and Medieval Strategies for the Afterlife (Stroud: 2008), p. 124 .

45 Julie M. Candy, The Archaeology of Pilgrimage on the Camino de Santiago de Compostela: a Landscape Perspective, BAR Int. Ser. 1948 (Oxford, 2009), p. 4. 
brought to England by Matilda, daughter of Henry I. ${ }^{46}$ Such an acquisition would have been a major draw for pilgrims. Moreover, Winchester was only $15 \mathrm{~km}$ from the bustling port of Southampton where many pilgrims would have arrived from, or embarked on, pilgrimages overseas. Winchester, served by its own important shrines, was thus a key focal point in a wider pilgrim network. This then raises a question concerning the wider landscape context of the leprosarium at Winchester, and to what extent it might have fitted into a wider network of religious sites in the landscape.

\section{Hospitals in the Landscape: A Spiritual Network?}

The medieval urban hinterland was a landscape imbued with meaning. Springs, ancient paths, hills, churches, monasteries, hermitages and hospitals together created a web of ciphers and symbols that made up an interconnected and sacred landscape. In particular, religious institutions, through their patronal saints and holy communities, invested these hinterlands with dynamic spiritual significance. In Winchester, Derek Keene has argued that the "physical ordering of Winchester from the 9th to 12th century was informed by a succession of powerful ideologies and models." ${ }^{27}$ Here, certain groups of churches such as St James and St Anastasius by virtue of their placement at the suburban limits or on hill tops close to the city may have "come to express Winchester's role as a point of departure for places of pilgrimage overseas and itself a destination for pilgrims." 48 Other churches in the hinterlands also followed this pattern and included the chapel of St Catherine (on St Catherine's Hill, to the south of the city), evoking perhaps Alexandria, Mount Sinai and the Holy Land; St Faith's, associated from the 11th century with the important pilgrimage to Conques; St Giles, associated with the pilgrim centre at Gilles de Garde; and St Cross providing perhaps a symbolic association between

46 Cherry, "The Depiction of St James Compostela," p. 40.

47 Derek Keene, "Early Medieval Winchester: Symbolic Landscapes," in Lords and Towns in Medieval Europe: The European Historic Towns Atlas Project, ed. Anngret Simms and Howard B. Clarke (Farnham, 2015), pp. 419-45, at p. 443. Here it is interesting to note that the influential Bishop of Winchester, Henry de Blois (1129-71), was possibly accused by the Cistercian Bernard of Clairvaux of intending to make Winchester a second Rome. Bishop Henry also petitioned, unsuccessfully, for Winchester to be a made an archbishopric around this time. See also Jeffrey West "A Taste for the Antique? Henry of Blois and the Arts," ANS 30 (2008), 213-30.

48 Keene, "Early Medieval Winchester," p. 436. 
Winchester and Jerusalem. ${ }^{49}$ Significantly, Keene goes on to mention the leprosy hospital at St Mary Magdalen claiming that its refoundation in the 12th century would have "reinforced Winchester's association with pilgrimage, Jerusalem and the Resurrection" (Fig. 25.5). ${ }^{50}$

The presence of St Mary Magdalen, and therefore the inclusion of its community in this symbolic ordering, again reinforces the explicit status of people with leprosy and their hospitals in the 11th and 12th centuries. In this context, leprosaria were not segregated or excluded groups of outcasts but fundamental constituents of medieval urban social and religious life. Moreover, the specific location of leprosy hospitals on the boundaries of medieval towns can be viewed as occupying a peculiar, yet distinctive, liminal place in the medieval landscape. As noted, at Norwich five leprosy hospitals occupied positions by the entrances to the city. At Old Sarum, the hospital was positioned just outside the entrance to the early Norman town and castle and on the junction between three major roads. As at Winchester, these hospitals can rather be seen as important and integral components of a broader sacred landscape. Rather than outcasts, in some cases these communities were endowed with divine favour; the institutions acted as spiritual guardians marking and protecting the approaches to medieval towns and cities. At Winchester, many of the churches might have had some visual association and would have been visible, along with the Cathedral, from valley bottom to the south of the city by visitors travelling to or from the continental port at Southampton..$^{51}$ In particular, the hilltop locations of St Mary Magdalen, together with St Giles and St Catherine's chapels, would have provided prominent landmarks, interconnected and visually prominent from both within the city and its approaches. Here, St Mary Magdalen was not only physically connected, but also visually and spatially interconnected to other landscape features and religious institutions, contributing to a complex network of sacralisation in the medieval urban hinterland.

Past perceptions and traditional histories of people with leprosy add little to a progressive and informed academic debate on the subject. The implications of such views are particularly acute today where in many parts of the world people still experience leprosy (Hansen's Disease) and related discriminative and prohibitive legislation. Despite this, recent years have witnessed a reassessment of the evidence, and questioned the idea of the 'medieval leper' as outcast. The evidence from 12th-century Winchester, when placed into this

49 Keene, "Early Medieval Winchester," pp. 438-39.

5o Keene, "Early Medieval Winchester," p. 440.

$5^{1} \quad$ Keene, "Early Medieval Winchester," p. 438. 


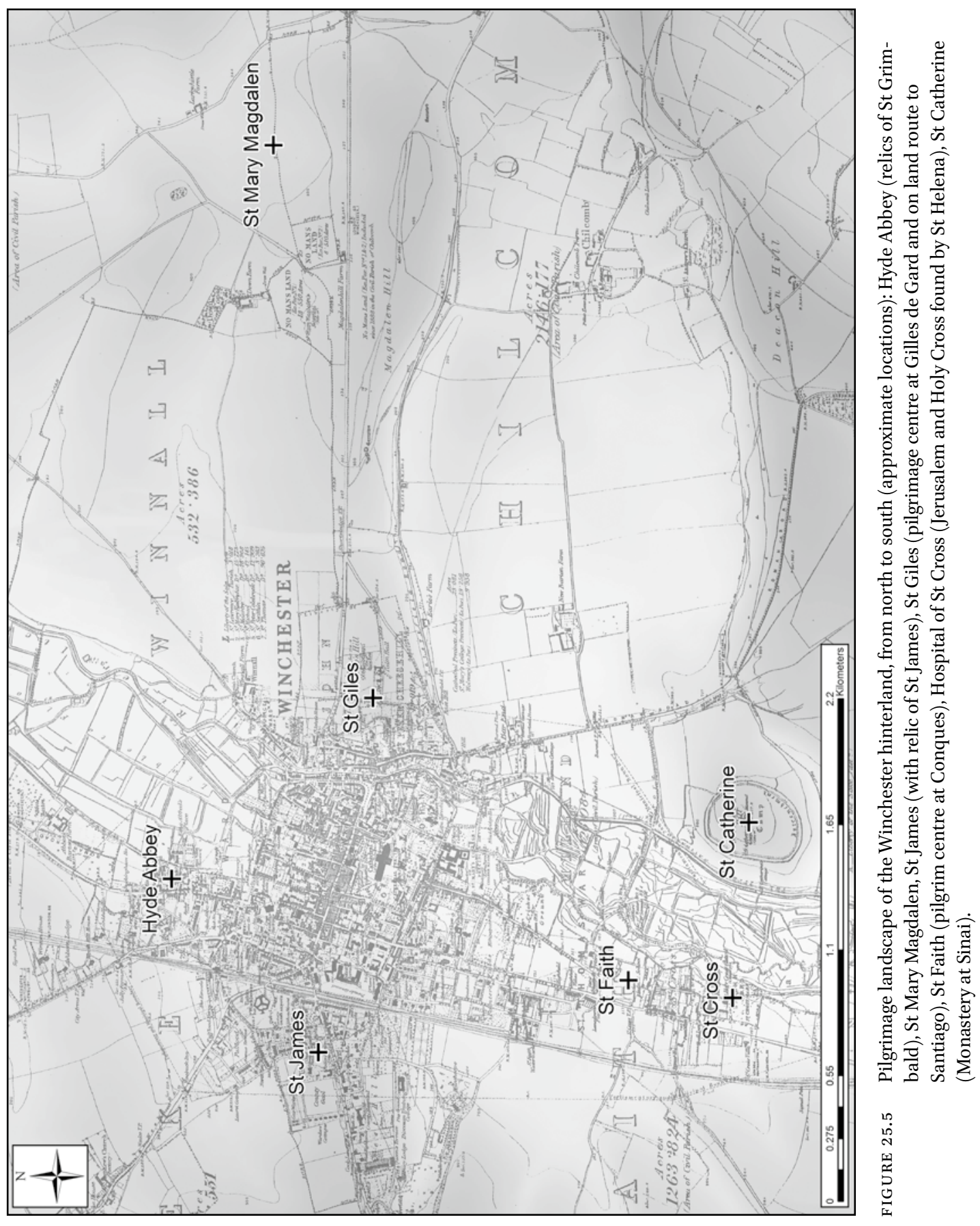


context, further challenges these long-held assumptions and suggests, that at least in this case, hospitals were communities of leprosy sufferers who may have carried their disease as a religious calling. Here, such communities may have contributed to a wider symbolic landscape of religious institutions in the wider urban and suburban landscapes. Ultimately, in this light we can see the first leprosaria of the late 11th and early 12 th centuries as being more akin to religious communities rather than segregated communities of outcasts. In this light, they may have served as an innovative institutional, and formally religious, component of a long standing tradition of early medieval health-care and healing. Far from being excluded from early medieval society they were an integral component of it. However, it is likely that such a situation was relatively short-lived, and leprosy as a religious vocation was not, in general, destined to survive beyond the $13^{\text {th }}$ century. ${ }^{52}$ It is possible that as the disease continued to spread during the later 12 th and 13 th centuries, and coupled with a growing awareness of disease transmission and contagion, these early communities morphed into more formal institutions. This may have also coincided with the development of clearer defined and more explicit (and explanatory) church legislation. Now, although the church might decree that leprosy was a gift of God, its bishops and priest would nonetheless increasingly use the disease as a useful and familiar metaphor for spiritual degeneration. ${ }^{53}$ By the 1180 s at Winchester, the simple timber buildings, chapel and cemetery had been replaced by masonry buildings and a more formal organised arrangement introduced. This included a large masonry infirmary and a formal cloister. It was also a period when the hospital began to appear more prominently in the historical records. ${ }^{54}$ Initial excavation of the later cemetery at Winchester revealed burials that were less defined, non-anthropomorphic and truncated and overall in stark contrast to the earlier burials.

Winchester in the late 11th and early 12th centuries was still a city of some national importance and this is reflected by the impressive programme of rebuilding initiated by the early Norman kings and bishops. Furthermore, Winchester continued to represent a powerful symbol of secular and religious authority, and it may be that the community at St Mary Magdalen was unique in this context. Yet, this may not necessarily be the case and more archaeological research needs to be conducted on early, or 'first phase', leprosy hospitals, a period, as at Winchester, that may often predate any documented histories.

$52 \quad$ Rawcliffe, Leprosy in Medieval England, p. 59.

53 Brody, Disease of the Soul, p. 61.

54 There is no documentary reference to the hospital or community at Winchester prior to 1148 , during the 60 or 70 years after its first archaeologically-dated phases. 
Such research, it is hoped, will begin to shed more light on the status of such early leprosaria and their communities in the 11th and early 12th centuries, as well as Anglo-Saxon precedents. It will move to provide an alternative picture to the 'medieval leper' as outcast and further help to challenge traditionallyderived misconceptions of a disease that is very much alive today. 